\title{
Peran Motivasi terhadap Peningkatan Kinerja Karyawan di PT Surya Eden Utama Makassar
}

\author{
Fadlina*1 \\ A. Katini Sari Putri D.2 \\ Nova Pratiwi ${ }^{3}$ \\ 1,2,3Program Studi Manajemen, STIE Ichan Sidenreng Rappang, Indonesia \\ *e-mail: fadlinadamis22@gmail.com ${ }^{1}$, aksputrid@gmail.com ${ }^{2}$, novapratiwi55@gmail.com ${ }^{3}$
}

(Naskah masuk : tgl bln thn, Revisi : tgl bln thn, Publikasi : tgl bln thn)

\begin{abstract}
Abstrak
Tujuan dari penelitian ini adalah untuk mengetahui peranan motivasi terhadap peningkatan kinerja karyawan di PT. Surya Eden Utama Makassar. Penelitian ini menggunakan metode pengumpulan data penelitian pustaka dan penelitian lapang. Analisis data yang digunakan adalah analisis deskriptif dan analisis koefisien determinasi. Hasil analisis koefisien determinasi untuk pengujian peranan motivasi $(X)$ terhadap peningkatan kinerja karyawan (Y) di PT. Surya Eden Utama Makassar berpengaruh positif signifikan dengan hasil perhitungan analisis bahwa nilai determinasi adalah 0,90. Motivasi kerja dan kinerja karyawan dapat ditingkatkan apabila sistem pemberian insentif didasarkan pada motivasi kerja dan tingkat kemampuan daripada karyawan.
\end{abstract}

Kata kunci: Insentif, Kinerja dan Karyawan, Motivasi

\begin{abstract}
The purpose of this study was to determine the role of motivation on improving employee performance at PT. Surya Eden Utama Makassar. This study uses the method of collecting data from library research and field research. Analysis of the data used is descriptive analysis and analysis of the coefficient of determination. The results of the analysis of the coefficient of determination for testing the role of motivation (X) on improving employee performance (Y) at PT. Surya Eden Utama Makassar has a significant positive effect with the results of the analysis calculation that the value of determination is 0.90. Work motivation and employee performance can be improved if the incentive system is based on work motivation and level of ability rather than employees.
\end{abstract}

Keywords: Incentives, Motivation, Performance and Employe

\section{PENDAHULUAN}

Sumber daya manusia termasuk salah satu sumber daya yang paling penting dan dominan dalam mengantar perusahaan mencapai tujuan, Tersedianya modal, peralatan (mesin) dan komponen-komponen lainnya tanpa didukung oleh kualitas sumber daya manusia yang memadai, maka sulit memperoleh laba yang besar. Oleh karena itu, efektif tidaknya penggunaan komponenkomponen yang dimiliki perusahaan sangat bergantung pada kualitas sumber daya manusia yang dimiliki.

Kualitas sumber daya manusia dapat diperoleh melalui beberapa upaya, diantaranya; pemberian pendidikan dan pelatihan, pembinaan disiplin, pemberian sanksi yang tegas dan penilaian prestasi kerja. Peningkatan kualitas sumber daya manusia tidak akan ada artinya tanpa dilandasi dengan motivasi yang tinggi dan kemauan yang besar sehingga mendorong dirinya lebih maju dan berkembang sesuai dengan kemampuannya. Indikator utama yang harus dimiliki seseorang dalam mencapai tujuan tertentu adalah bagaimana menumbuhkan motivasi tersebut, mereka dapat berusaha untuk memenuhi kebutuhan dan keinginannya melalui usaha dan kerja keras.

Motivasi sangat berhubungan dengan faktor psikologis seseorang yang mencerminkan hubungan atau interaksi antara sikap, kebutuhan dan kepuasan yang terjadi pada diri manusia sehingga dapat mempengaruhi kinerjanya. Tanpa motivasi, orang tidak akan dapat melakukan sesuatu. Motivasi yang timbul dari dalam diri manusia yang disebut dengan intrinsik dan sumber dari luar diri manusia yang disebut ekstrinsik. PT. Surya Eden Utama Makassar adalah salah satu 
perusahaan yang bergerak dalam bidang penjualan rumah (property) dan dalam kegiatannya harus ditunjang dengan adanya motivasi, baik yang timbul dari dalam diri maupun dari luar diri manusia. Sehubungan dengan ini, maka penulis akan memfokuskan pembahasan tentang motivasi yang timbul dari luar diri manusia (ekstrinsik), yaitu gaji/Insentif, tunjangan hari raya, jaminan kesehatan, kebutuhan keamanan dan kebutuhan aktualisasi diri.

Menurut Mitchell dalam Winardi (2002:1) bahwa: ... "motivasi mewakili proses-proses psikologikal, yang menyebabkan timbulnya, diarahkannya, dan terjadinya persistensi kegiatankegiatan sukarela (valunter) yang di arahkan kea rah tujuan tertentu". Sedangkan menurut Manahan (2004:80) bahwa Motivasi adalah berhubungan erat dengan bagaimana perilaku itu dimulai, dikuatkan, disokong, diarahkan, dihentikan, dan reaksi subjektif macam apakah yang timbul dalam organisasi ketika semua ini berlangsung.

Berdasarkan uraian di atas,maka yang menjadi permasalahan dalam penelitian ini adalah apakah peran motivasi kerja dalam bentuk (gaji/Insentif, tunjangan hari raya, jaminan kesehatan, kebutuhan keamanan dan kebutuhan aktualisasi diri) berpengaruh signifikan terhadap kinerja karyawan? Tujuan dari penelitian ini adalah untuk mengetahui Peranan Motivasi dalam Meningkatkan Kinerja Karyawan di PT. Surya Eden Utama Makassar.

\section{METODE}

Penelitian ini dilakukan di PT. Surya Eden Utama Makassar yang bergerak di bidang penjualan rumah (property). Populasi dalam penelitian ini adalah semua karyawan tetap dan kotrak selama lima tahun (2013-2017) yang berjumlah 320 orang. Sugioyono (20011:38) berpendapat bahwa variabel penelitian pada dasarnya adalah segala sesuatu yang berbentuk apa sja yang ditetapkan oleh peneliti untuk dipelajari sehingga diperoleh informasi tentang hal tersebut, kemudian ditarik kesimpulannya. Untuk penelitian ini variabel bebas (independent variable) adalah peranan motivasi (X) sedangkan varibel terikat (dependent variable) adalah kinerja karyawan $(\mathrm{Y})$.

Data yang diperlukan penelitian ini adalah data primer yang diperoleh dari hasil observasi dan wawancara langsung dengan pihak-pihak yang terkait dalam perusahaan dan data sekunder yang diperoleh dari dari dokumen-dokumen serta bahan-bahan tertulis lainnya dari perusahaan yang bersangkutan yang erat hubungannya dengan penelitian ini. Dalam rangka menyatukan persepsi dalam penelitian ini maka dirumuskan defenisi operasionalnya. Adapun defenisi operasional dalam penelitian ini adalah "peranan motivasi dalam meningkatkan kinerja karyawan pada PT. Surya Eden Utama Cabang Makassar" dimaksudkan bahwa motivasi yang diberikan kepada karyawan berdampak positif dalam rangka meningkatkan kinerja Adapun indikator adalah:

1. Motivasi merupakan suatu proses untuk menumbuhkan semangat yang mendorong individu untuk bertindak dan bekerja giat untuk mencapai hasil yang optimal.

2. Kinerja/prestasi kerja adalah hasil kerja yang dicapai seseorang karyawan dalam melaksanakan tugas yang dibebankan kepadanya.

3. Insentif adalah penghargaan dalam bentuk uang yang diberikan kepada mereka yang dapat bekerja melampaui standar yang telah ditentukan.

4. Motivasi ekstrinsik yaitu motivasi yang timbul karena adanya faktor dari luar diri manusia dan tidak tergantung pada tugas yang dilaksanakan tetapi dikendalikan pihak lain, faktor ini dapat berupa gaya kepemimpinan seorang atasan, dorongan atau bimbingan seseorang, perkembangan situasi dan sebagainya.

5. Karyawan (karyawan, tenaga kerja, personalia) adalah orang-orang yang dipekerjakan pada sebuah badan usaha atau organisasi bisnis yang turut membantu proses kegiatan usaha. Perkembangan situasi dan sebagainya.

Untuk membuktikan hipotesis yang diajukan maka digunakan metode analisis : Analisis deskriptif, digunakan untuk menjelaskan peranan peranan motivasi dalam meningkatkan kinerja karyawan pada PT. Surya Eden Utama Cabang Makassar. Untuk mengetahui pengaruh faktor yang mempengarui motivasi kerja, maka dipakai analisis koefisien determinasi sebagai berikut: 


$$
r=\frac{n \sum X Y-\sum X \cdot \sum Y}{\sqrt{\left(n \cdot \sum X^{2}-\left(\sum X\right)^{2}\right) \sqrt{ }\left(n \cdot \sum Y^{2}-\left(\sum Y\right)^{2}\right)}}
$$

Dimana:

$r=$ Koefisien korelasi yang bermaksud melihat hubungan insentif terhadap motivasi kerja karyawan.

$\mathrm{n}=$ Jumlah pemberian insentif / tahun

$\mathrm{x}=$ Jumlah insentif.

$\mathrm{y}=$ Tingkat insentif

\section{HASIL DAN PEMBAHASAN}

\subsection{Motivasi dan Prilaku Dalam Hubungannya Dengan Pengrealisasian Insentif Terhadap Karyawan}

Dapat diketahui bahwa pada Dinas Tenaga Kerja Kota Makasar, setiap golongan karyawan memandang insetif, apakah insentif itu berwujud material atau non material sebagai suatu proses untuk meningkatkan kegairahan kerja, akan tetapi insentif tersebut sejauh ini belum mampu membentuk suatu tingkah laku yang teroganisir, karena harapan karyawan yang dibawah sewaktu memasuki organisasi pada kantor tersebut belum terealisir sepenuhnya. Lain halnya dengan instansi sejenis dimana sumbangan tenaganya yang diabadikan pada instansi, seiring dengan harapan akan direalisasikan pemenuhannya sehinggah prilaku yang dibentuk searah dengan tujuan organisasi. Pengrealisasian pemenuhan kebutuhan tidak hanya ditinjau dari sudut kebendaan saja, akan tetapi lebih dari pada pemuasan kebutuhan non material turut pula merupakan indikator dalam pembentukan perilaku individu. Apakah individu tersebut akan melahirkan tergantung pada prestasi individu yang bersangkutan atas perlakuan terhadapnya.

Dengan demikian, maka naik turunya atau tinggi rendahnya motivasi kerja dapat dimonitor dari berbagai motif yang nampak oleh individu dalam tindak tanduknya setiap saat dalam instansi. Hal ini pula dapat dilaksanakan bilamana pengrealisasian balas jasa material dilaksanakan secara berimbang dan terpadu, disamping itu dapat diharapkan perilaku yang ditujukan membawa pengaruh positif dalam pengorbanan prestasi.

Jadi dengan demikian, maka kecenderungan bagi karyawan sebaiknya direalisasikan dalam bentuk material saja semata yang tercakup dalam penerimaan Insentif, sehinggah dapat menimbulkan kepuasan bagi diri mereka. Dengan demikian maka sangatlah tepat dikatakan bahwa masalah gaji/Insentif karyawan khususnya pada karyawan, sangatlah perlu diperhatikan oleh pihak perusahaan guna meningkatkan kinerja karyawan, dengan gaji yang rendah akan mempengaruhi seterusnya dapat melahirkan perilaku organisasi. Hal ini dapat terwujud bila antara instansi dan penghasil kerja mempunyai pengertian yang terkoordinir dengan baik.

Pada PT. Surya Eden Utama Makassar, setiap tingkatan/golongan karyawan memandang insentif, apakah insentif itu berwujud material atau non material. Perkembangan jumlah pendapatan yang diperoleh dari penjualan rumah perusahaan tidak terlepas dari jumlah karyawan sebagai ujung tombak pemasaran itu sendiri. Berikut ini disajikan tabel jumlah karyawan berdasarkan statusnya, sebagai berikut:

Tabel 1. Jumlah Karyawan Berdasarkan Status Pada Kantor Pt. Surya Eden Utama Makassar Tahun 2013 s.d 2017

\begin{tabular}{ccccc}
\hline Tahun & \multicolumn{2}{c}{ Status } & $\begin{array}{c}\text { Jumlah } \\
\text { Karyawan }\end{array}$ & $\begin{array}{c}\text { Perkembangan } \\
\text { Karyawan (\%) }\end{array}$ \\
\hline 2013 & 59 & 3 & 62 & - \\
2014 & 59 & 3 & 62 & - \\
2015 & 60 & 4 & 64 & 3.23 \\
2016 & 62 & 4 & 66 & 3.23 \\
2017 & 61 & 5 & 66 & 3.23 \\
\hline
\end{tabular}

Dari tabel tersebut diatas, tampak bahwa jumlah karyawan pada tahun 2013, adalah sebanyak 62 orang, dengan masing-masing jumlah karyawan tetap dan kontrak sebanyak 59 dan 3 orang. Kemudian tahun 2014, jumlah karyawan masing-masing karyawan tetap dan kontrak 
adalah sebanyak 59 dan 3 orang, jumlah keseluruhan 62 orang, dan tahun 2015, jumlah karyawan tetap dan kontrak sejumlah 60 dan 4 orang, jumlah keseluruhan sebanyak 64 orang, sedangkan tahun 2016, masing-masing karyawan tetap dan kontrak sejumlah 62 dan 4 orang, jumlah keseluruhan sebesar 66 orang, sedangkan pada tahun 2017 masing-masing karyawan tetap dan kontrak sebanyak 61 dan 5 orang, jumlah keseluruhan sebesar 66 orang

Tabel 2. Jumlah Insentif Karyawan Tetap Pada Kantor Pt. Surya Eden Utama Makassar Tahun 2013 s.d 2017

\begin{tabular}{ccc}
\hline Keterangan & Orang & Rupiah \\
\hline Pimpinan & 1 & 18.000 .000 \\
Sekretaris/Kep. Bagian & 8 & 67.200 .000 \\
Karyawan Tetap & 51 & 244.800 .000 \\
Jumlah & & 330.000 .000 \\
\hline
\end{tabular}

Dari tabel tersebut di atas nampak bahwa jumlah karyawan tetap sebanyak 60 orang, termasuk 1 (satu) orang Pimpinan. Adapun Insentif yang diterima oleh pimpinan sebesar Rp. 1.500.000 perbulan dan Sekertaris/Kepala Bagian sebesar Rp.700.000 perbulan. Selanjutnya untuk karyawan tetap kantor menerima Insentif sebesar Rp.400.000 perbulan dengan total penerimaan Insentif sebesar Rp. 330.000.000.

\subsection{Analisis Pengaruh Tentang Hubungan Antara Insentif dengan Motivasi Kerja}

Berdasarkan hasil wawancara pada Kantor PT. Surya Eden Utama Makassar, dalam hal ini Kepala Sub Bag Umum dan Kekaryawanan, dijelaskan bahwa karyawan tang terlibat langsung dalam penjualan masyarakat adalah karyawan tetap dan kontrak, maka dalam uraian ini dijelaskan pengaruh Insetif yang diberikan oleh Kantor DisnakerTrans khususnya karyawan tetap dengan motivasi kerjanya.

Analisis tersebut dimaksudkan untuk memperhitungkan atau memperkirakan besarnya pengaruh secara kuantitatif dari kantor Depnaker kota Makasar suatu kejadian terhadap kejadian lainnya. Dari hasil penganalisaan itulah nantinya yang dapat memberikan jawaban terhadap perubahan dalam dalam Kantor Dinas Tenaga Kerja Kota Makasar, misalnya dengan menaikkan tingkat Insentif apakah benar-benar mempengaruhi (menaikkan) prestasi/motivasi kerja atau tidak.

Tabel 3. Perkalian Variabel Karyawan Dengan Tingkat Insentif pada Tahun 2013 s.d 2017

\begin{tabular}{cccccc}
\hline Tahun & $\begin{array}{c}\text { Jumlah } \\
\text { Karyawan X }\end{array}$ & $\begin{array}{c}\text { Tingkat } \\
\text { Insentif } \mathbf{Y}\end{array}$ & $\mathbf{X Y}$ & $\mathbf{X}^{\mathbf{2}}$ & $\mathbf{Y}^{\mathbf{2}}$ \\
\hline 2013 & 59 & 354 & 20.886 & 3.481 & 125.316 \\
2014 & 59 & 424,8 & $250.63,2$ & 3.481 & $180.445,04$ \\
2015 & 60 & 504 & 30.240 & 3.600 & 254.016 \\
2016 & 62 & 669,6 & $41.515,2$ & 3.844 & $448.364,16$ \\
2017 & 61 & 732 & 44.652 & 3.721 & 535.824 \\
Jumlah & 301 & $2.684,4$ & $162.356,4$ & 18.127 & $1.543 .975,2$ \\
\hline
\end{tabular}

Setelah dilakukan evaluasi berdasarkan analisis dan ternyata dari evaluasi tidak sesuai dengan apa yang diharapkan, maka perlulah diadakan perubahan atau penyesuaian terhadap kebijaksanaan yang diambil, oleh karena itu kebijaksanaan harus selalu dapat disesuaikan dengan situasi dan kondisi pada waktu yang bersangkutan. Untuk menghitung korelasi antara jumlah karyawan pada Dinas Tenaga Kerja dan Transmigrasi Kota Makassar, maka dapat dilihat pada perhitungan berikut:

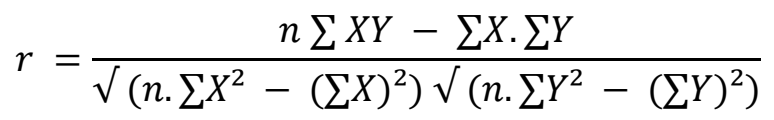




$$
\begin{aligned}
& r=\frac{5(162.356,4)-(301 \times 2.684,4)}{\sqrt{\left(5(18.127)-(301)^{2} \sqrt{\left(5(1.543 .975,2)-(2.684,4)^{2}\right.}\right.}} \\
& r=\frac{811.782-808.004,4}{\sqrt{90.635-60.601 \sqrt{7.719 .876-7.206 .003,36}}} \\
& r=\frac{3.777,6}{\sqrt{34 \sqrt{513.872,64}}} \\
& r=\frac{3.777,6}{4180} \\
& r=0,90 \\
& r=1
\end{aligned}
$$

Untuk mengetahui koefisien determinasinya sebagai berikut:

$$
\begin{aligned}
r^{2} & =(r)^{2} \times 100 \% \\
& =(1)^{2} \times 100 \% \\
& =100 \%
\end{aligned}
$$

Hasil perhitungan diatas, membuktikan bahwa nilai koefisien determinasi adalah $100 \%$ yang berarti variabel X terhadap $\mathrm{Y}$ berpengaruh 100\% atau dengan kata lain mempunyai pengaruh kerja karyawan adalah dengan pemberian insentif pada motivasi karyawan.

Hasil perhitungan analisis bahwa nilai determinasi adalah 0,90 yang artinya tingkat insentif terhadap motavasi kerja karyawan berpengaruh positif $100 \%$ yang berarti hipotesis dapat diterima.

\section{KESIMPULAN}

Berdasarkan pada hasil analisis dan dan pengujian hipotesis, dapat ditarik kesimpulan bahwa. Motivasi kerja dan kinerja karyawan dapat ditingkatkan apabila sistem pemberian insentif didasarkan pada motivasi kerja dan tingkat kemampuan daripada karyawan. Dalam merealisasikan pemberian Insentif beserta tunjangan lainnya terhadap karyawan tetap maupun kontrak yaitu apabila mencapai target yang telah ditentukan maka dapat memperoleh tambahan atau bonus lebih banyak sesuai yang telah ditentukan oleh Kepala Kantor Dinas Tenaga Kerja dan Transmigrasi Kota Makassar. Hasil perhitungan analisis bahwa nilai determinasi adalah 0,90 yang artinya tingkat insentif terhadap motavasi kerja karyawan berpengaruh $100 \%$ yang berarti hipotesis dapat diterima.

Karena keterbatasan waktu maka variabel-variabel dalam penelitian ini dibatasi hanya pada peran motivasi (ekstrinsik : gaji/Insentif, tunjangan hari raya, jaminan kesehatan, kebutuhan keamanan dan kebutuhan aktualisasi diri) dan kinerja karyawan. Peneliti tidak dapat menjelaskan lebih spesifik mengenai hasil penelitian tentang Peran Motivasi Terhadap Peningkatan Kinerja Karyawan Di PT. Surya Edan Utama karena merupakan kerahasiaan perusahaan.

\section{DAFTAR PUSTAKA}

Ahmad, J., Hasan, A. ul, Naqvi, T., \& Mubeen, T. (2019). A Review on Software Testing and Its Methodology. Manager's Journal on Software Engineering, 13(1), 32-38. https://doi.org/10.26634/jse.13.3.15515

Alwi, S. (2001). Manajemen Sumber Daya Manusia. Penerbit BPFE, Yogyakarta.

Anonim, (2000). Undang-undang Otonomi Daerah 1999 dan Juklak. Cetakan pertama, Penerbit Sinar Grafika, Jakarta. 
Arikunto, \& Suharsimi. (1997). Proseduer penelitian Suatu Pendekatan Praktek, Penerbit Bumi Aksara, Jakarta.

Girosudarmo, I., \& Sudita, N. (2000). Perilaku Keorganisasian. Penerbit BPFE, Yogyakarta.

Hasibuan, S. M. (2006). Manajemen Sumber Daya Manusia. Penerbit: Bumi Aksara, Jakarta.

Irawan, dkk. (1997). Manajemen Unjuk Kerja. Penerbit Gramedia. Jakarta.

Kusharyanto, \& Bambang. (1997). Manajemen Personalia, Liberty, Yokyakarta.

Moekijat. (1999). Manajemen Sumber Daya Manusia (Manajemen Kekaryawanan). Penerbit CV. Mandar Maju, Bandung.

Moelyono. (1997). Kamus Besar Indonesia. Penerbit Gramedia, Jakarta.

Nawawi, H. H. (1998). Manajemen Sumber Daya Manusia. Cetakan Ke Tiga. Penerbit: Gadjah Mada University Press, Yogyakarta.

Fhathoni, A. R. (2006). Manajemen Sumber Daya Manusia. Penerbit: PT. Rinka Cipta, Jakarta.

Panggabean, S. M. (2002). Manajemen Sumber Daya Manusia. Penerbit: Ghalia Indonesia, Jakarta. Sarwoto. (1997). Dasar-dasar Organisasi Manajemen. Penerbit Ghalia Indonesia, Jakarata.

Sujak, \& Abi, (2000). Manajemen Personalia, Edisi Kelima, Cetakan Pertama, Yokyakarta. BPFE.

Sularso, \& Sri. (2003). Metode Penelitian Akuntansi: Sebuah Pendekatan Replikasi. Edisi 2003/2004. Cetakan Pertama. Penerbit BPFE-Yogyakarta, Yogyakarta.

Tampubolon, \& Mahana, P. (2004). Perilaku Keorganisasian. Penerbit Ghalia Indonesia, Jakarta.

Winardi, J. (2002). Motivasi dan Pemotivasian Dalam Manajemen. Penerbit Raja Grafindo Persada, Jakarta.

Wursanto, I. G. (2003). Manajemen Kekaryawanan 1. Cetakan Ke 10. Penerbit: Kanisius (Anggota IKAPI), Yogyakarta 